\title{
THE RELATIONSHIP BETWEEN THE HEALTH BELIEF MODEL AND DRUG INFORMATION SERVICES PROVIDED BY PHARMACISTS TO PREGNANT AND BREASTFEEDING WOMEN
}

\author{
Septi Anggraini ${ }^{1}$ Wahyu Utami $^{2}$ Elida Zairina ${ }^{2}$ \\ ${ }^{1}$ Master's Program in Pharmacy, Faculty of Pharmacy, Airlangga University,Surabaya, Indonesia \\ ${ }^{2}$ Department of Community Pharmacy, Faculty of Pharmacy, Airlangga University, Surabaya, Indonesia \\ Correspondence Address: Elida Zairina \\ E-mail: elida-z@ff.unair.ac.id
}

\begin{abstract}
The use of medication during pregnancy and breastfeeding cannot be avoided, particularly for those with chronic diseases. The use of medication for these patients require special attention, especially by pharmacists as they have the responsibility to provide medications and appropriate services to achieve optimal therapeutic goals. The drug information service actively provided by pharmacists is a display of their commitment in preventing drug therapy problems and improving the quality of life of pregnant and breastfeeding women. This study aimed to analyze the relationship between pharmacists' beliefs based on the Health Belief Model (HBM) approach and the practice of active drug information service for pregnant and breastfeeding women with chronic diseases. This study was an observational study with a cross-sectional design and used a self-administered questionnaire. 62 pharmacists in Primary Healthcare Centers in Surabaya agreed to participate in this study. The Spearman correlation analysis was used and showed that perceived self-efficacy had the strongest relationship $\left(\mathrm{r}_{\mathrm{s}}=0.357\right)$ with the practice of providing active drug information. Thus, it can be concluded that perceived self-efficacy is a factor that is directly related to the practice of providing active drug information.
\end{abstract}

Keywords: Active Drug Information Services, Health Belief Model, Pharmacists

\section{INTRODUCTION}

The use of drugs during pregnancy and breastfeeding - especially in pregnant and nursing patients with chronic diseases cannot be avoided. In some countries such as Brazil, Ethiopia, and India, the prevalence of pregnant women suffering from chronic diseases were high with $39 \%$ for respiratory disease, $11 \%$ for hypertension, and 9\% for diabetes (Kassada et al., 2015; Abeje, Admasie, and Wasie, 2015; Gogoi and Unisa, 2017). In Surabaya, the prevalence of high-risk pregnant women or complications handled in health facilities has reached $90.24 \%$ of 9,496 people (Surabaya City Health Office, 2017).

The high prevalence of pregnant and nursing patients with chronic diseases is followed by high levels of non-compliance with drug use during pregnancy. Data shows that $36.2 \%$ of pregnant women in Europe, America, and Australia, and 64\% of pregnant women in Ethiopia did not take drugs during pregnancy (Lupattelli, Spigset, and Nordeng, 2014; Abeje, Admasie, and Wasie, 2015). Furthermore, research in Surabaya revealed that $25 \%$ of drug therapy problems in pregnant women was due to non-compliance (Dewi et al., 2014).

The reason why patients are not compliant in using drugs is the concern about their effects on the fetus, and that they are more conservative and skeptical (Abeje, Admasie, and Wasie, 2015; Zaki and Albarraq, 2014). This is influenced by limited information related to drug use and the risk of side effects (Zaki and Albarraq, 2014). The absence of therapy in maternal health conditions can cause greater harm to the condition of the fetus and mother than the side effects of the prescribed drugs (Lupattelli, Spigset, and Nordeng, 2014).

Drug information services given by pharmacists through leaflets/booklets can help patients understand their disease and improve their adherence to the medication (Shareef et al., 2016; Murdiyanti, Putri, and 
Minarsih, 2017). Pharmacists as personnel who are responsible for providing drug information to patients must have sufficient knowledge and confidence about the importance of drug information services when providing their services to pregnant and breastfeeding mothers with chronic diseases.

Pharmacists as health workers who know about drugs are obliged to provide drug information to pregnant and breastfeeding patients with chronic diseases. However, several studies in Indonesia showed that pharmacists are still passive in providing information regarding the provision of drug information and only provide limited information. That is, they only provide drug information when questions arose (Baroroh, 2014; Mayefis, Halim and Rahim, 2015; Athiyah et al., 2014; Athiyah et al., 2014; Harlianti et al., 2016).

This study focused on the practice of providing drug information services actively. Active drug information service means that the pharmacist provides information without waiting for questions from patients. The practice of actively providing drug information is based on the pharmacist's commitment to provide responsible services to patients.

This study aims to analyze the relationship between pharmacists' beliefs based on the Health Belief Model (HBM) approach and the practice of active drug information service for pregnant and breastfeeding women with chronic diseases.

Based on the Health Belief Model theory developed by Renstrok in 1966, a person takes an action based on their beliefs and cues to act (Champion and Skinner, 2008). This is belief in the dangers that might occur if the provision of drug information is not optimal (Perceived Threat), confidence in the benefits if the provision of drug information is given to pregnant and breastfeeding patients (Perceived Benefits), the belief that there are obstacles that may occur in providing drug information to pregnant patients and breastfeeding (Perceived Barriers), and the belief that pharmacists can provide active drug information to pregnant and breastfeeding patients with chronic diseases (Perceived Self-efficacy). It is these beliefs that drives pharmacists to actively provide drug information to pregnant and breastfeeding patients with chronic diseases.

\section{METHOD}

This study was an observational study with a cross-sectional design and used a self-administered questionnaire. The respondents in this study were pharmacists. The data collection was conducted with an entire population of 63 pharmacists in primary healthcare centers.

The instrument used in this study was a questionnaire which consisted of three questionnaires. The pharmacist's knowledge questionnaire was designed by researchers using several references such as Drugs During Pregnancy and Lactation (2015), the Pharmacotherapy Handbook (2015), and Applied Therapeutics (2013). The questionnaire consisted of 15 questions and consisted of five aspects, including knowledge about absorption, distribution, metabolism, and elimination (ADME) of medicine, knowledge of safe drugs for chronic diseases in pregnancy and breastfeeding conditions, knowledge of drugs that have teratogenic effects, knowledge about how to use the right medicine during pregnancy and breastfeeding, and knowledge about how to obtain sources of information. The questionnaire consisted of true and false answers. The total score of between $0-15$ was obtained by adding up all the correct answers.

The questionnaire for belief and pharmacists' cues to action was designed to measure the beliefs of the pharmacists and cues to action that encourage the pharmacists to provide drug information services to pregnant women and nursing mothers with chronic diseases. The 
pharmacist confidence questionnaire consisted of perceived threats, benefits, barriers, and self-efficacy. This questionnaire used a 5-point Likert scale (5: strongly agree, 4: agree, 3: doubtful, 2: disagree, 1: strongly disagree). The total score of the pharmacist's confidence ranges between 15-75 while the total score for the gesture to act ranges from $4-20$.

The pharmacist's practice questionnaire was designed by researchers to measure the pharmacists's practice in providing drug information services to patients with chronic illness during pregnancy and breastfeeding. The drug information service in question is a form of active service where drug information service is initiated by the pharmacist without waiting for questions from patients. The questionnaire consisted of 15 statements that measure the frequency of drug information services provided by pharmacists, with a 3-point Likert scale (3: always, 2: once, and 1: never). Additional statements about examples of facilities or props available at the health center were also mentioned. All of the questionnaires used in this study met the reliability and validity of the instrument.

Data analysis was performed by using the IBM SPSS Statistics 23 software. The data normality analysis used the Kolmogorov-Smirnov test. The analysis of the relationship of beliefs (which included perceived threat, benefits, barriers, selfefficacy, and cues to action) with the practice was measured by using the Spearman correlation test.

This study has received permission from the Surabaya City Health Office (Dinas Kesehatan Kota Surabaya) (No.072/7016/436.7.2/2019). This study has also obtained ethical approval as issued by the Health Research Ethics Commission of the Faculty of Public Health, University of Airlangga (No. 56/EA/KEPK/2019).

\section{RESULTS}

Sixty-two pharmacists participated in this study since one primary healthcare center was excluded. The majority of pharmacists $(83.9 \%)$ were female and aged between 29-37 years. All pharmacists have served pregnant and nursing patients. Primary healthcare centers provide the maternal and child health care polyclinic (poli klinik kesehatan ibu dan anak) as a place to care for the health of mothers and children. Pharmacists at the healthcare center are accustomed to serving pregnant women patients with prescriptions for supplements and vitamins, mild illness symptoms, and complaints of chronic diseases such as hypertension, diabetes, and asthma. The majority of the pharmacists sampled (35.5\%) have between 6-10 years of work experience (Table 1).

Table 1. Sociodemography Characteristics of Pharmacists $(n=267)$

\begin{tabular}{lc}
\hline \multicolumn{1}{c}{ Sociodemography Characteristics of Pharmacists } & $\mathbf{n}(\boldsymbol{\%})$ \\
\hline Age, Median (IQR) & $34.5(29-37) *$ \\
\hline Gender & \\
\hline Male & $10(16.1)$ \\
\hline Female & $52(83.9)$ \\
\hline Period of Service & $3(4.8)$ \\
\hline$<1$ year & $16(25.8)$ \\
\hline $1-5$ years & $22(35.5)$ \\
\hline $6-10$ years & $21(33.9)$ \\
\hline$>10$ years & \\
\hline Last Education & $62(100)$ \\
\hline Pharmacist & $0(0)$ \\
\hline Master's Degree
\end{tabular}




\section{Experience in attending seminars or training related to drug use in} pregnant and breastfeeding women

\begin{tabular}{lc}
\hline 0 time & $42(67.7)$ \\
\hline 1 time & $16(25.8)$ \\
\hline Characteristics of Sociodemography of Pharmacists & $\mathbf{n}(\boldsymbol{\%})$ \\
\hline 2 times & $3(4.8)$ \\
\hline 3 times & $0(0)$ \\
\hline$>3$ times & $1(1.6)$ \\
\hline Experience in serving pregnant and breastfeeding women & $62(100)$ \\
\hline Ever & $0(0)$ \\
\hline Never
\end{tabular}

*Median (IQR)

\section{Pharmacists' Knowledge}

Pharmacists' knowledge related to the use of drugs for chronic diseases during pregnancy and breastfeeding fell into the good category. The knowledge measured included knowledge about absorption, distribution, metabolism, and drug elimination (ADME), use of chronic disease drugs, teratogenic effects of chronic disease drugs, the safety of drug use, and tracking of drug information. The descriptive analysis conducted through a questionnaire showed that most of the pharmacists sampled had good knowledge. However, on the aspect of knowledge about the use of chronic disease drugs in pregnant and breastfeeding patients, $62.3 \%$ of pharmacists showed poor knowledge (Figure 1).

\section{Pharmacists' Belief and Cues to Action in Active Drug Information Service Practice}

The results of the the pharmacist confidence analysis showed that more than $80 \%$ of pharmacists at the health center felt that providing non-optimal drug information is dangerous, while $15.2 \%$ of pharmacists felt that it was quite dangerous. A total of $81.5 \%$ of pharmacists felt that giving drug information to pregnant and breastfeeding patients with chronic diseases was beneficial and $18.5 \%$ felt that it was quite beneficial. All pharmacists felt to some degree that there is danger in providing sub-optimal drug information and no pharmacist denied the benefits of providing drug information to pregnant and nursing patients with chronic diseases.

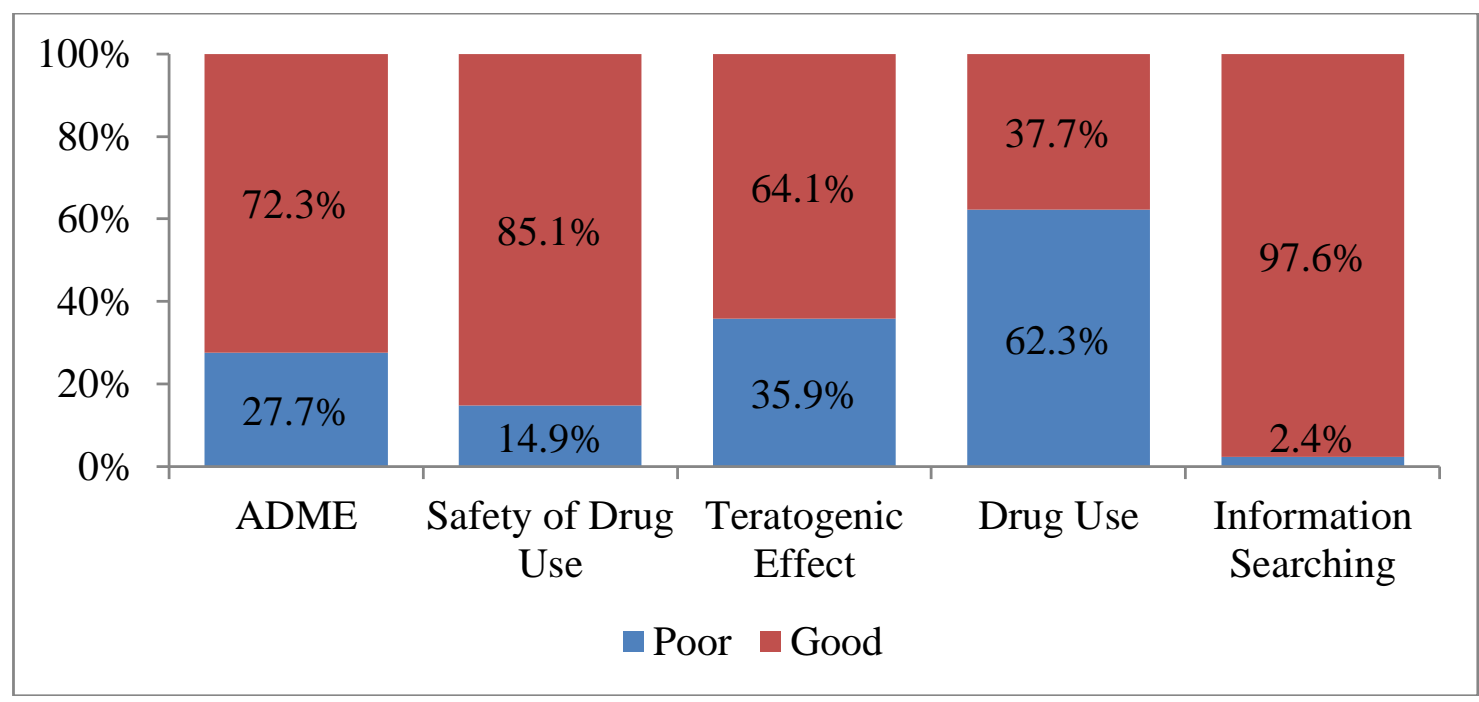

Figure 1. Diagram of Pharmacists' Knowledge 
Analysis of perceived barriers or pharmacists' perceived obstacles in providing active drug information showed that $62 \%$ of pharmacists at the health center felt quite inhibited from providing information and $37.7 \%$ of pharmacists felt barriers when providing information. Only $0.3 \%$ of pharmacists they realize they could be more active in providing information. Analysis of perceived self-efficacy by pharmacists showed that the majority of pharmacists felt confident in providing active drug information to pregnant and breastfeeding patients, but there were still pharmacists who lacked confidence. More than $90 \%$ of pharmacists showed high encouragement in providing active drug information or cues to action and this was from their own internal drive (Figure 2).

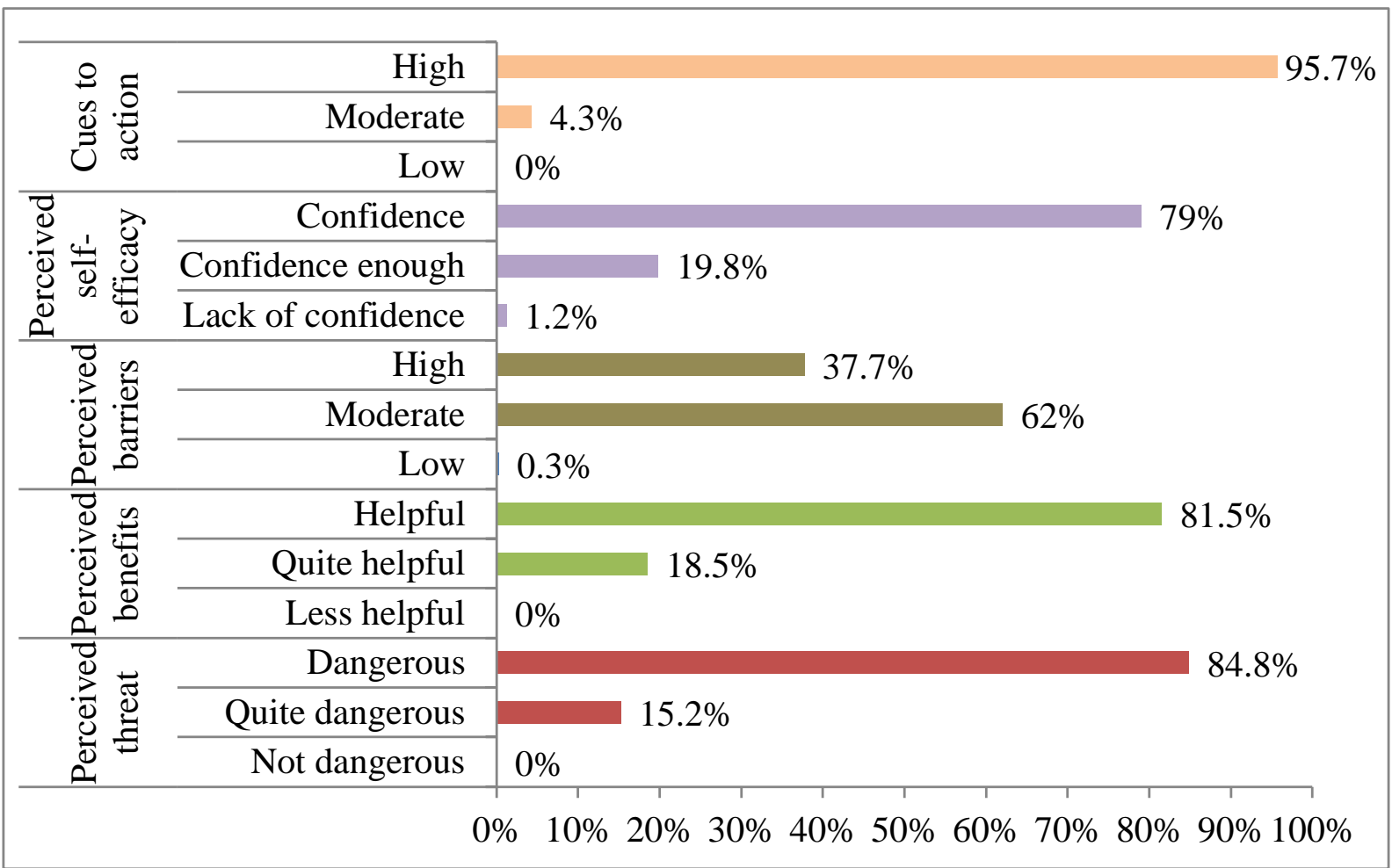

Figure 2. Diagram of the Beliefs and Cues to Action for Pharmacists in Providing Information Services on Chronic Disease Medication to Pregnant and Breastfeeding Women

\section{Practice of Active Drug Information Provision}

The results have shown that $94.8 \%$ of pharmacists had poor practices regarding active practice of drug information provision and only $0.6 \%$ had good practices. Active practice means the provision of materials such as leaflets/booklets, facilities usage, and counseling. In these three aspects, more than $80 \%$ of pharmacists fell into the poor category.

Based on the median value of the practice, pharmacists at health centers tend to utilize the facilities or teaching aids they had. This is reinforced by information given by pharmacists through leaflets and brochures that have been provided by the maternal and child healthcare polyclinic, which are based on the professional work practices of pharmacists or services from the Surabaya City Health Office. The procurement of means of providing drug information such as leaflets and booklets were general information related to chronic diseases and the use of antibiotics. The most widely used media means are leaflets.

The practice of providing drug information that pharmacists rarely use is 
counseling. Generally, pharmacists at the healthcare center provide counseling at Integrated Healthcare Centers (Pos Pelayanan Terpadu). However, the material presented would only be in the form of lifestyle suggestions or methods for procuring, using, storing, and disposing of medicine (DApatkan, GUnakan, SImpan, BUang obat or DAGUSIBU). The topic of drug use during pregnancy would only be given as additional information when there are questions or discussions related to this topic.

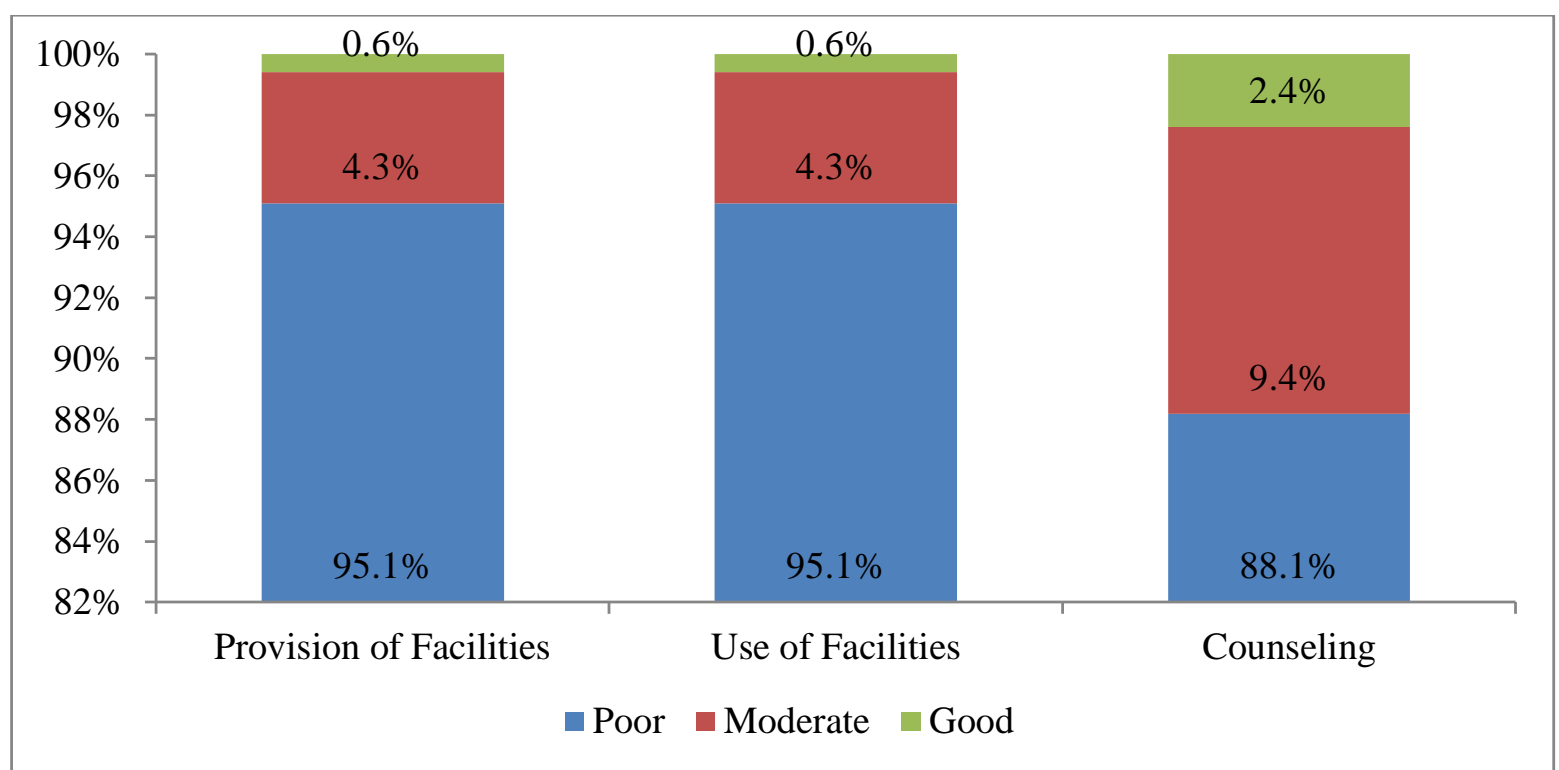

Figure 3. Pharmacists' Practice in Providing Information Services on Chronic Disease Medication to Pregnant and Breastfeeding Women

Relationship between Beliefs, Cues to Action, and Active Information Provision Practice

Analysis on the relationship between perceived threat, benefits, barriers, self-efficacy, cues to action, and active practice of providing information was performed by using the Spearman correlation analysis. The results of the analysis showed that the strength of the relationship between perceived self- efficacy and the practice of providing drug information is the strongest relationship among the other variables. This is indicated by the value of the correlation coefficient being $r_{s}=0.357$ (Table 2). The relationship is deemed positive with moderate strength if it falls between 0.1-0.29 (Pallant, 2016). Whereas perceived threat is the independent variable that has the weakest relationship with the practice of providing drug information $\left(r_{s}=0,021\right)$.

Table 2. Result of the Spearman Correlation Analysis

\begin{tabular}{llcc}
\hline \multicolumn{1}{c}{ Independent Variables } & Dependent Variables & $\mathbf{r}_{\mathbf{s}}$ & $\boldsymbol{p}$ \\
\hline Perceived Threat & The practice of Active & 0,021 & 0,870 \\
\cline { 3 - 4 } Perceived Benefits & Drug Information & $-0,067$ & 0,605 \\
\cline { 3 - 4 } Perceived Barriers & Distribution & 0,033 & 0,797 \\
\cline { 3 - 4 } Perceived Self-Efficacy & & $0,357^{*}$ & 0,004 \\
\hline Cues to Action & & 0,023 & 0,857 \\
\cline { 3 - 4 } & &
\end{tabular}

$\mathrm{r}_{\mathrm{s}}$ : Correlation coefficients Spearman; $p$ : Probability value; *: There is a significant correlation 


\section{DISCUSSION}

Pharmacists have the responsibility to provide education to patients regarding the correct use of drugs to achieve the best therapeutic results and improve their quality of life. Pharmacists must have good knowledge of their field and specific attitudes that can help influence their behavior in practice. The specific attitude required is altruism (behavior that prioritizes the happiness and welfare of others) (Montagne and McCarthy, 2005). Thus, not only do pharmacists conduct their obligations according to regulations, but they also have a strong commitment to carry out practices that focus on achieving expected therapeutic outcomes and improve the quality of life of patients.

In this study, one of the pharmacists' commitments that was analyzed was their practice of actively providing information the restrictions of the use of chronic disease medicines to pregnant and breastfeeding patients. Active practice of providing drug information means that the pharmacist provides drug information without waiting for questions. Such practice shows that the pharmacists have a great commitment towards improving the quality of life of patients. The active provision of drug information could be done by verbal communication through counseling or by writing through leaflets and booklets (Sheehan and Abel, 2005; Shareef et al., 2016; Murdiyanti, Putri and Minarsih, 2017).

Female and male pharmacists of various ages have the same belief in the dangers, benefits, barriers, and ability to provide drug information to pregnant and breastfeeding patients with chronic diseases. This can be caused by the obligation of all pharmacists to continue to learn and improve their competence through training, seminars, and practices as a condition for recertification (National Pharmacy Committee, 2014). This obligation requires all pharmacists to develop their competence. Thus, the beliefs formed are related to the use of drugs during pregnancy and breastfeeding and is not limited by gender or age.

Pharmacists' knowledge regarding the use of medicine for chronic diseases during pregnancy and breastfeeding mostly fell into the poor category. This lack of knowledge can be caused by the absence of training or seminars related to drug use for pregnant and breastfeeding patients (Table 1). The ability of pharmacists to update and assess information received is an obstacle experienced by pharmacists in the community. Several studies conducted in various countries has shown similar results. A study by Alrabiah et al. (2017) stated that pharmacists in Saudi Arabia had limited knowledge regarding the use of drugs during pregnancy due to the lack of education and training programs received. Other studies conducted in Canada, Qatar, and Uganda showed that the majority of pharmacists did not receive sufficient training regarding medicine taken during pregnancy and breastfeeding (Bains et al., 2014). Research in Kuwait also showed that more than half of the pharmacists sampled did not receive sufficient training on this topic (Albassam and Awad, 2018).

The majority of pharmacists at the health center sampled in this study believed that providing sub-optimal drug information is dangerous towards the health of pregnant and breastfeeding patients with chronic diseases. They considered that providing active drug information would benefit pregnant and breastfeeding patients with chronic diseases. Providing drug information to nursing patients is an important component to improve the patient's health condition (Ponti et al., 2015). However, regarding the practice of providing actionable information, pharmacists believed that there were obstacles. The barrier included the limited knowledge and ability to trace drug information (Grinceviciene et al., 2015). As many as $79 \%$ of pharmacists were confident in providing drug information to pregnant and nursing patients with chronic diseases. 
Cues to action is the factor that encourages pharmacists to actively provide information to the patients. The analysis showed that $95.7 \%$ of pharmacists felt a high urge to actively provide information. The greatest encouragement perceived by pharmacists to provide actionable information provision is the fact that pregnant and breastfeeding patients are a group of patients who are prone to experiencing problems with medicine use.

The pharmacists' perceived selfefficacy regarding the active practice of providing drug information to pregnant and breastfeeding patients with chronic diseases are a form of their confidence in actively providing information. The test results showed that the value of the correlation coefficient between perceived self-efficacy and practice is 0.357 . This result indicates that the strength of the relationship between perceived self-efficacy and active information-giving practices is moderate and positive. Therefore, the greater the pharmacist's perceived self-efficacy, the better the active practice of information provision. Similar research results were shown in a study conducted in Lithuania where it was found that there is an increase in the practice of drug information services for pregnant and nursing patients when the pharmacists are also highly confident (Grinceviciene et al., 2015). Government and professional organizations can improve the active practice of providing information at healthcare centers through increasing the pharmacist's perceived self-efficacy. Seminars or training could be conducted regularly to increase the knowledge and skills of pharmacists related to the use of medicine for pregnant and breastfeeding women with chronic diseases (Rouf et al., 2018).

Based on the results of the analysis obtained it can be concluded that the pharmacists' internal factor that has the strongest relationship with active drug information services is perceived selfefficacy. External factors such as workload, facilities, and support from health workers can also be factors associated with the active information-giving practice. The high workload at the health center without an adequate number of pharmacy workers would mean that the pharmacists do not have adequate time to practice optimally (Hermansyah, 2017). Government support and collaboration with professional organizations to create standards and guidelines to improve the application of pharmaceutical care in healthcare centers is needed (Puspitasari et al., 2015).

In this study, several advantages are prioritized in research. Based on our information searches, there is no research related to the practice of active provision of drug information by pharmacists in Indonesia. The main topic and focus on which this researched is based is the commitment of pharmacists in providing practices per the responsibilities of the pharmacist profession to improve the quality of life of patients. This study provided information related to knowledge, pharmacists' perceptions and practice of providing information in healthcare centers and pharmacies related to drugs pregnant and breastfeeding women with chronic diseases. The results of this study can be used as evaluation material for pharmacist practices in the community to increase the role of pharmacists in improving the quality of life of pregnant and breastfeeding patients.

The limitation of this study is the data collection for the practice of drug information provision by pharmacists was conducted only once, therefore the information provided is less than optimal. This study also did not involve pregnant and breastfeeding patients as research respondents. Therefore, the analysis of active drug information practice can only be reviewed from the pharmacists' point of view.

The results of this study can be used as a basis for conducting further research to analyze the factors that affect pharmacists when providing active drug information services. Further studies could be done to 
investigate the effect of external factors on pharmacists and their information provision practices. Additionally, more extensive analysis of community pharmacists in clinics, pharmacies, and pregnant and breastfeeding patients are needed to obtain more complete data, and qualitative research and a cohort approach are needed for deeper analysis.

\section{CONCLUSION}

The factors associated with active drug information service practices for pregnant and breastfeeding patients are pharmacists' perceived self-efficacy. Perceived threats, benefits, barriers, and cues to action are not significantly related to the active practice of drug information service for pregnant and breastfeeding patients with chronic diseases. Efforts can be made to actively increase the practice at healthcare centers through seminars and training to improve pharmacists' knowledge and skills.

\section{REFERENCE}

Abeje, G., Admasie, C. and Wasie, B. (2015) 'Factors Associated With Self Medication Practice Among Pregnant Mothers Attending Antenatal Care At Governmental Health Centers In Bahir Dar City Administration, Northwest Ethiopia, A Cross Sectional Study', The Pan African medical journal, 20, $\quad$ pp. $276 . \quad$ doi: 10.11604/pamj.2015.20.276.4243.

Albassam, A. and Awad, A. (2018) 'Community Pharmacists' Services For Women During Pregnancy And Breast Feeding In Kuwait: A CrossSectional Study', BMJ Open, 8(1), pp. 1-8. doi: 10.1136/bmjopen2017-018980.

Alrabiah, Z., Alarifi, M. N., Alghadeer, S. M., Wajid, S., Alqahtani, A., Almotari, N., Alhwerani, A., and Babelghaith, S.D. (2017)
'Knowledge of community pharmacists about the risks of medication use during pregnancy in central region of Saudi Arabia', Saudi Pharmaceutical Journal. King Saud University, 25(7), pp. 1093-1096. doi: 10.1016/j.jsps.2017.05.005.

Athiyah, U., Riskayanti, E., Rakhmawati, F.D, Nugraheni, G., and Nita, Y. (2014) 'Profil Informasi Obat Pada Pelayanan Resep Metformin dan Glibenklamid di Apotek di Wilayah Surabaya', Jurnal Farmasi Komunitas Vol, 1(1), pp. 6-11.

Bains, S., Kitutu, F. E., Rahhal, A., Samaha, R. A., Wilby, K. J., and Rowe, H. (2014) 'Comparison Of Pharmacist Knowledge, Perceptions And Training Opportunities Regarding Maternal-Fetal Medicine In Canada, Qatar And Uganda', Canadian Pharmacists Journal 147(6), pp. 345-351 doi: $10.1177 / 1715163514552558$.

Baroroh, F. (2014) 'Kefarmasian Di Apotek Kota Yogyakarta Evaluation Of Costumer Satisfaction With Pharmaceutical Care At Pharmacy In Yogyakarta, Pharmaciana, 4 (2), pp. 135-141.

Champion V. L. and Skinner C. S. (2008) Health and Health. 4th Edn. Edited by Karen Glanz; Barbara K. Rimer; K. Viswanath. United States of America: John Wiley \& Sons, Inc.

Dewi, C. P., Nita, Y., Priyandani, Y., and Yuda, A. (2013) 'Identifikasi Drug Therapy Problems Pada Pelayanan Resep Untuk Ibu Hamil', Jurnal Farmasi Komunitas 1(1), pp. 12-17.

Gogoi, M. and Unisa, S. (2017) 'Women's Health Chronic Diseases During Pregnancy And Birth Outcome: A Study Based On Tertiary Hospital Of Mumbai', J, 317140(2), pp. 6168. doi: 10.17140/WHOJ-3-123.

Grinceviciene, S., Kubiliene, L., Ivanauskas, K., Drasutiene, G.S., Ramasauskaite, D., Grinceviciues, 
J., Bernatoniene, J., and Savickas, A. (2015) 'Experiences Of Community Pharmacists Advising Pregnant Women', International Jouranl of Clinical Pharmacy 37(1), pp. 636-644. doi: 10.1007/s11096015-0111-6.

Harlianti, M. S., Andayani, T. M., and Puspandari, D. A. (2016) 'Pengaruh Kepuasan Terhadap Kemauan Membayar (Willingness To Pay) Jasa Pelayanan Konseling Oleh Apoteker', 4(1), pp. 26-30.

Hermansyah, A. (2017) 'Investigating The Impact Of The Universal Healthcare Coverage Programme On Community Pharmacy Practice', pp. 1-12. doi: 10.1111/hsc.12506.

Kassada, D. S., Miasso, A. I., Waidman, M. A. P., and Marcon, S. S. (2015) 'Prevalence And Factors Associated With Drug Use In Pregnant Women Assisted In Primary Care', Text Context Nursing, 24 (3), pp. 713721. doi: 10.1590/010407072015002770013.

Lupattelli, A., Spigset, O. and Nordeng, H. (2014) 'Adherence To Medication For Chronic Disorders During Pregnancy: Results From A Multinational Study', International Journal of Clinical Pharmacy, 36(1), pp. 145-153. doi: 10.1007/s 11096-013-9864-y.

Mayefis, D., Halim, A. and Rahim, R. (2015) 'Pengaruh Kualitas Pelayanan Informasi Obat terhadap Kepuasan Pasien Apotek X Kota Padang (Effect of Drug Information Service Quality Patient Satisfaction City Pharmacy X Padang)', Jurnal Ilmu Kefarmasian Indonesia 13(2), pp. 201-204.

Montagne, M. and McCarthy, R. L. (2005) Ethics and Professionalism. In: Troy, D. Remington: The Science and Practice of Pharmacy $21^{\text {st }}$ Edition. Philadelphia: Lippincott Williams and Wilkins, pp. 23.

Murdiyanti, D., Putri, P. and Minarsih, D.
W. (2017) 'Metode Booklet

Diabetes Melitus ( DM ) Meningkatkan Kepatuhan Penyandang DM Dalam Manajemen Regimen Terapeutik', Jurnal Keperawatan YKY Yogyakarta 1 (1), pp. 41-50.

National Pharmaceutical Committee (2014) 'Pedoman Re-Sertifikasi Apoteker Dan Penentuan Nilai Satuan Kredit Partisipasi (SKP)'. Jakarta: National Pharmaceutical Committee.

Pallant, J. (2016) 'SPSS Survival Manual: A Step by Step Guide to Data Analysis Using IBM SPSS 6th edn' United State of America: Open University Press, pp. 155.

Ponti, M., Stewart, K., Amir, L. H., and Hussainy, S. Y. (2015) 'Medicine Use And Safety While Breastfeeding: Investigating The Perspectives Of Community Pharmacists In Australia', Journal of Primary Health 25(1), pp. 46-57. Puspitasari, H. P., Aslani, P. and Krass, I. (2015) 'Challenges In The Management Of Chronic Noncommunicable Diseases By Indonesian Community Pharmacists', pp. 1-12. doi: 10.18549/PharmPract.2015.03.578.

Putri, D. M. P. and Minarsih, D. W. (2017) 'Metode Booklet Diabetes Melitus (DM) Meningkatkan Kepatuhan Penyandang DM dalam Manajemen Regimen Terapeutik', Jurnal Keperawatan YKY Yogyakarta 1 (1), pp. 41-50.

Rouf P. A., Thomas, B., Elkassem, W., Tarannum, A., Al Saad, D., Gasim, M. M., and Al Hail, M. (2018) 'Knowledge And Practice Characteristics Of Pharmacists In Qatar Towards Medication Use In Pregnancy: A Cross-Sectional Survey', Eastern Mediterranean Health Journal 24(2), pp. 137-145.

Surabaya City Health Office (2017) 'Profil Kesehatan Kota Surabaya', Surabaya: Surabaya City Health 
Office, pp. 194.

Shareef, J., Fernandes, J., Samaga, L. and Bhat, M. (2016) 'Development, Quality And Readability Assessment Of Patient Information Leaflet For Diabetes Mellitus', Diabetes and Obesity International Journal 1 (2), pp. 1-5. doi: 10.19080/CRDOJ.2016.01.555560.

Sheehan, A.H and Abel S. R. (2005) Professional Communications. In: Troy, D. Remington: The Science and Practice of Pharmacy $21^{\text {st }}$ Edition. United States of America: Lippincortt Williams and Wilkins, pp 1808.

Zaki, N. M. and Albarraq, A. A. (2014) 'Use, Attitudes And Knowledge Of Medications Among Pregnant Women: A Saudi Study', Saudi Pharmaceutical Journal, 22 (5), pp. 419-428.

doi: 